\title{
EVALUASI MATERI PENDIDIKAN ISLAM PERSPEKTIF GENDER \\ (Evaluasi Terhadap Materi Buku Ajar Agama Islam)
}

\author{
Syafrida \\ Dosen Fakultas Tarbiyah dan Kependidikan \\ EmIL: Syafrida-ida@gmail.com
}

\begin{abstract}
Education is a tool for transferring the norms of society, knowledge and human capabilities, as well as a tool to assess and convey ideas and new values, including the values and norms of gender. It is known that many gender inequality occurred in society are assumed to arise because there is a gender bias in education, including religious education. As an example of gender bias in the curriculum of Islam among the materials about the origin of human events, the obligation to pray in congregation, the provisions of polygamy, spousal function in marriage. In an effort to realize the religious understanding of the nature of gender, then it should be required revisions to matters of gender bias in textbooks of the Islamic religion. It should be stressed also awareness about the value of education gender perspective to all parties, especially the author and editor of books on the fact that the curriculum is not gender neutral. Meanwhile, for the religious teachers are required to be more critical and sensitive in identifying and examine all matters relating to gender inequality in the learning process that takes place in their daily work.
\end{abstract}

Keywords: Gender, Textbooks, Islam

\begin{abstract}
Abstrak: Pendidikan merupakan alat untuk mentransfer norma-norma masyarakat, pengetahuan dan kemampuan manusia, juga sebagai alat untuk mengkaji dan menyampaikan ide-ide dan nilai baru, termasuk nilai dan norma gender. Diketahui telah terjadi banyak ketimpangan gender di masyarakat yang diasumsikan muncul karena terdapat bias gender dalam pendidikan, termasuk pendidikan agama. Sebagai contoh bias gender dalam kurikulum agama Islam di antaranya pada materi tentang asal kejadian manusia, kewajiban salat berjama'ah, ketentuan poligami, fungsi suami-istri dalam munakahat. Dalam upaya mewujudkan pemahaman keagamaan yang bersifat gender, maka sudah selayaknya diperlukan revisi terhadap hal-hal yang bias gender dalam buku ajar Agama Islam tersebut. Perlu ditekankan pula penyadaran tentang nilai-nilai pendidikan yang berperspektif gender kepada semua pihak khususnya para pengarang dan editor buku tentang kenyataan bahwa kurikulum yang ada tidak netral gender. Sementara itu, bagi para guru agama dituntut untuk lebih kritis dan sensitif dalam menelaah dan mencermati segala hal yang terkait dengan ketimpangan gender dalam proses pembelajaran yang berlangsung dalam kerja kesehariannya.
\end{abstract}

Kata Kunci: Gender, Buku ajar, Islam

\section{PENDAHULUAN}

Pendidikan merupakan aktivitas yang khas bagi manusia dalam suatu komunitas masyarakat dengan tujuan untuk memanusiakan manusia, 1 dan merupakan instrumen yang penting bagi pemberdayaan masyarakat, terutama bagi masyarakat yang termarjinalkan. ${ }^{2}$ Pendidikan juga merupakan kunci terwujudnya keadilan gender dalam masyarakat, karena di samping merupakan alat untuk mentransfer norma-norma masyarakat, pengetahuan dan kemampuan manusia, juga sebagai alat untuk mengkaji dan menyampaikan ide-ide dan nilai baru. Dengan demikian, lembaga pendidikan merupakan sarana formal untuk sosialisasi sekaligus transfer nilai-nilai dan normanorma yang berlaku dalam masyarakat, 
Syafrida, Evaluasi Materi Pendidikan Islam Perspektif Gender...

termasuk nilai dan norma gender. Nilai dan norma tersebut ditransfer secara lugas maupun secara tersembunyi, baik melalui buku-buku teks yang digunakan maupun pada suasana dan proses pembelajaran.

Sebagaimana diketahui telah terjadi banyak ketimpangan gender di masyarakat yang diasumsikan muncul karena terdapat bias gender dalam pendidikan termasuk pendidikan agama. Di antara aspek yang menunjukkan adanya bias gender dalam pendidikan dapat dilihat pada perumusan kurikulum. Implementasi kurikulum pendidikan sendiri terdapat dalam buku ajar yang digunakan di sekolah-sekolah. Realitas yang ada, dalam kurikulum pendidikan (agama ataupun umum) masih terdapat banyak hal yang menonjolkan laki-laki berada pada sektor publik sementara perempuan berada pada sektor domestik. Dengan kata lain, kurikulum yang memuat bahan ajar bagi siswa belum bernuansa netral gender baik dalam gambar ataupun ilustrasi kalimat yang dipakai dalam penjelasan materi.

Demikian halnya dalam materi agama, sebagai contoh dalam materi asal kejadian manusia, kewajiban salat berjama'ah, ketentuan poligami, fungsi suami-istri dalam munakahat. yang banyak mengandung bias gender. Hal ini mungkin terjadi dikarenakan dalil-dalil (argumen hukum) yang diambil sebagai rujukan berasal dari kita-kitab klasik yang penuh dengan budaya patriarkhi.
Selain itu semakin mengentalnya kecenderungan bias gender ini dikarenakan para penulis buku menganggap kitab fiqh yang menjadi rujukkannya sebagai sesuatu yang final, sakral tidak bisa diubah.

Realitas ini jelas akan menghantar pada gambaran sosok perempuan yang lemah secara fisik dan psikis dibandingkan laki-laki. Akhirnya, citra perempuan dengan berbagai aspek negatifnya, mendarah daging seiring sejalan dengan sejarah manusia dan kemanusiaan itu sendiri. ${ }^{3}$

\section{TINJAUAN TEORITIS}

\section{Gender dalam Diskursus Sosial}

Analisis terhadap status dan peran perempuan Islam Indonesia menghasilkan kesimpulan yang beragam. Hal tersebut disebabkan oleh adanya perbedaan sudut pandang dan pendekatan dalam mencermati hubungan gender dan dinamika interaksi yang terjadi dalam hubungan gender pada masyarakat dan budaya Indonesia. ${ }^{4}$ Kajian gender merupakan reaksi terhadap ketimpangan peran sosial antara laki-laki dan perempuan, dan ketidakadilan gender yang terjadi di masyarakat. ${ }^{5}$

Kata gender dan sex sebenarnya berbeda, kedua kata ini semakin penting untuk dibedakan karena ada kaitan erat antara perbedaan gender (gender differences) dan ketidakadilan gender dengan struktur 
ketidakadilan masyarakat secara lebih luas. Kata sex berasal dari bahasa Inggris yang berarti jenis kelamin. ${ }^{6}$ Kata sex dalam kamus lain dijelaskan, "Sex is the characteristics which distinguish the male from the female". ${ }^{7}$ Sex adalah ciri-ciri yang membedakan antara jenis kelamin laki-laki dan perempuan yang bersifat biologis. Misalnya jenis laki-laki adalah manusia yang memiliki penis, jakum, memproduksi sperma dan seterusnya. Sedangkan perempuan adalah manusia yang memiliki alat reproduksi seperti rahim, memproduksi sel telur, memiliki vagina, payudara, dan lain-lain.

Menurut kamus Bahasa Inggris, kata gender diartikan sebagai "the grouping of words into masculine, feminine and neuter, according as they are regarded as male, female or without sex". Artinya gender adalah kelompok kata yang mempunyai sifat maskulin, feminim, atau tanpa keduanya/netral. 8 Mosse berpendapat, konsep gender pada dasarnya berbeda dari jenis kelamin biologis. Jenis kelamin biologis laki-laki atau perempuan merupakan pemberian dari Tuhan, akan tetapi jalan yang menjadikan maskulin atau feminim adalah gabungan antara blok-blok bangunan biologis dasar dan interpretasi biologis oleh kultur sosial. ${ }^{9}$

Sejalan dengan pendapat Mosse tersebut, Mansour Fakih ikut mempertegas bahwa harus dibedakan kata gender dengan kata sex. 10 Pengertian sex merupakan pensifatan atau pembagian dua jenis kelamin manusia yang ditentukan secara biologis dan melekat pada jenis kelamin tertentu, secara permanen tidak berubah atau sering dikatakan sebagai kodrat atau ketentuan Tuhan. Kata gender adalah suatu konsep yang mengacu pada peran-peran dan tanggung jawab laki-laki dan perempuan sebagai hasil konstruksi sosial dan kultural yang dapat diubah sesuai dengan perubahan zaman.

Berdasarkan uraian di atas dapat disimpulkan bahwa kata gender dan sex adalah berbeda. Sex adalah jenis kelamin yang bersifat biologis dan kodrati/pemberian dari Tuhan yang bersifat permanen, sedangkan gender adalah perbedaan tingkah laku (behavioral differences) antara laki-laki dan perempuan yang secara sosial dibentuk (socially constructed). Perbedaan tingkah laku dan peran yang bukan kodrat ini dibentuk melalui proses sosial budaya yang panjang, dan dapat berubah sesuai dengan kondisi zaman. Perubahan konsep gender pada masyarakat dapat terjadi melalui proses sosialisasi, yaitu proses menanamkan nilai-nilai dan adat istiadat masyarakat tertentu. Sosialisasi gender tidak statis, melainkan berlangsung terus menerus selama masih ada kehidupan di dunia ini. Peran gender mengambil bentuk dalam peran sosial, seperti peran seseorang 
pada sektor domestik dan publik. ${ }^{11}$ Dengan demikian peran gender merupakan peran laki-laki dan perempuan yang sering dikaitkan dengan status.

Peran gender sebenarnya dapat dipertukarkan dan hal tersebut sangat tergantung pada kondisi dan situasi masyarakat di mana dia berada. Peran seseorang dapat dikelompokkan ke dalam tiga bagian, yaitu: 1. Peran publik atau disebut peran produktif (productive work), 2. Peran domestik atau disebut peran reproduktif (reproductive work), 3. Peran sosial kemasyarakatan

(community managing/manajemen komunitas). Ketiga peran itu biasanya sering dilakukan perempuan sehingga disebut "tiga serangkai peran perempuan" atau "triple roles". ${ }^{12}$

Peran publik atau peran produktif adalah kegiatan seseorang yang berkaitan dengan pekerjaan yang dihargai dengan uang ataupun barang. Produktif mempunyai arti bersifat menghasilkan. mendatangkan, memberi manfaat, hasil dan sebagainya. Dengan demikian pekerjaan perempuan di dalam rumah maupun di luar rumah apabila menghasilkan uang, maka berarti perempuan tersebut telah melakukan peran produktif.

Peran domestik atau peran reproduktif adalah kegiatan seseorang yang terkait dengan fungsi reproduksi dan tidak menghasilkan uang atau barang. Contoh fungsi reproduksi perempuan adalah hamil, melahirkan, dan menyusui. Dengan demikian peran mendidik anak, mengasuh, memberi makan anak dan keluarganya dibebankan kepada perempuan, padahal sebenarnya laki-laki dengan fungsi reproduksinya menghasilkan sperma dan membuahi sel telur sehingga menghasilkan janin, seyogyanya laki-laki mempunyai tanggung jawab yang sama dalam mendidik dan mengurus anak. Namun pada kenyataannya peran tersebut dibebankan kepada perempuan, dan dianggap sebagai kodrat perempuan.

Peran berikutnya adalah peran sosial kemasyarakatan atau manajemen komunitas yaitu aktivitas seseorang sebagai anggota masyarakat, seperti: kegiatan sosial, kegiatan keagamaan, dan lain-lain. Peran ini dilakukan oleh laki-laki dan perempuan dalam komunitasnya sebagai anggota masyarakat yang perlu sosialisasi dan berinteraksi dengan anggota masyarakat lainnya. Berdasarkan hal tersebut dapat disimpulkan bahwa laki-laki dan perempuan dapat berkiprah dalam ketiga peran tersebut dan masing-masing peran dapat berubah sesuai dengan kondisi zaman.

Peran, atribut dan identitas gender seperti digambarkan di atas, selanjutnya dibentuk dan mendapat peran menurut konstruksi budaya masyarakatnya. Beberapa pandangan sosial budaya yang membedakan peran dan kedudukan antara laki-laki dan perempuan memberikan stereotype yang berbeda-beda. Sebagai contoh seorang laki- 
laki dikonstruksi masyarakat sebagai sosok yang kuat, gagah dan berani, sehingga masyarakat memberi peran produktif, aktif pada dunia publik, maskulin dan sebagai pencari nafkah utama. Sebaliknya seorang perempuan dikonstruksi masyarakat sebagai sosok yang lemah-lembut, cengeng, dan emosional, karenanya perempuan diberi peran reproduktif, domestik, bersifat feminim dan dianggap sebagai pencari nafkah tambahan. Selain itu menurut Arief Budiman pembagian kerja secara seksual sudah berlangsung ribuan tahun, karena itu orang cenderung menganggapnya sebagai suatu yang alamiah. ${ }^{13}$ Perbedaan peran yang dimiliki perempuan dan laki-laki sama nilainya.

Stereotype yang diberikan masyarakat terhadap perempuan dan laki-laki tersebut merupakan peran jenis (sex role), peran jenis adalah perilaku spesifik yang diharapkan dan dipergunakan sebagai standar yang diterapkan pada perempuan dan laki-laki. Kalau terjadi penyimpangan maka subjek dianggap tidak mengikuti norma-norma yang berlaku. Peran jenis yang diberikan kepada perempuan dan laki-laki dapat melahirkan perbedaan peran-peran yang ditentukan secara sosial, yang pada masingmasing masyarakat berbeda dalam menentukan peran tersebut, sehingga tidak ada peran gender yang benar-benar sama antara satu kultur dengan kultur lainnya.
Sesungguhnya perbedaan peran tidak akan menjadi masalah selama tidak terjadi ketimpangan yang berakhir pada ketidakadilan gender. ${ }^{14}$ Gender tidak sematamata mempersoalkan perbedaan dan pembedaan saja antara laki-laki dan perempuan; terlebih penting lagi ia menyangkut dominasi baik dari konteks relasi maupun distribusi kekuasaan. ${ }^{15}$ Kondisi inilah -disadari atau tidak- yang seringkali melahirkan dan melembagakan berbagai ketidakadilan yang seringkali diskriminatif pada laki-laki dan perempuan terhadap sesuatu yang didasarkan atas pembagian kerja menurut kategori jenis kelamin dan asumsi ideologi patriarki. Akibat kuatnya ideologi gender yang patriarkis yang berkembang di masyarakat ini, maka laki-laki dan perempuan tidak mempunyai kebebasan untuk menentukan pilihan peran-peran sosial dan kultural karena secara faktual ketidakadikan gender telah termanifestasikan dalam pelbagai bentuk keyataan sosial, budaya, ekonomi, politik dan agama.

Jika ditelusuri keberlangsungan keterpurukkan perempuan salah satunya dilatarbelakangi oleh "kekurangarifan" dalam menafsirkan dalil-dalil agama Islam yang kemudian seringkali dijadikan dasar utuk menolak kesetaraan jender. Kitab-kitab tafsir dijadikan referensi untuk melegitimasi paradigma patriarki, yang memberikan hak- 
hak istimewa kepada laki-laki dan cenderung memojokkan perempuan dengan pendefinisian yang negatif. Pendefinisian sosok perempuan yang negatif ini kemudian diwariskan secara turun temurun yang pada akhirnya mengendap dalam alam bawah sadar perempuan yang menimbulkan ketimpangan relasi antara laki-laki dan perempuan dalam hubungannya sebagai hamba tuhan. Dengan kata lain pemahaman akan posisi perempuan yang bias gender sudah dengan sendirinya tertradisikan di masyarakat yang dibakukan oleh konstruksi budaya dan doktrin keagamaan serta ditopang oleh nilai-nilai kultural dan ideologis.

Sementara itu menurut Masdar. F. Mas'udi ketidakadilan dan diskriminasi terhadap perempuan dalam masyarakat disebabkan oleh banyak faktor. Pada awalnya adalah disebabkan adanya stereotype yang cenderung merendahkan posisi kaum perempuan, seperti bahwa perempuan itu lemah, lebih emosional daripada nalar, cengeng tidak tahan banting, tidak patut hidup selain di dalam rumah, dan sebagainya. 16 Menurutnya ada empat persoalan yang menimbulkan stereotype terhadap perempuan;

1. Melalui subordinasi, ${ }^{17}$ kaum perempuan harus tunduk kepada kaum laki-laki. Pemimpin (imam) hanya pantas dipegang oleh laki-laki, sedangkan perempuan hanya boleh menjadi yang dipimpin (ma'mum). Perempuan boleh menjadi pemimpin hanya terbatas pada kaumnya saja, yang berfungsi sebagai pendukung kegiatan utama kaum lakilaki, misalnya di Dharma Wanita, Muslimat, Aisyiah, Fatayat dan sebagainya.

2. Perempuan cenderung dimarginalisasi, ${ }^{18}$ yaitu diposisikan dipinggir. Dalam kegiatan masyarakat, perempuan paling tinggi hanya menjadi seksi konsumsi atau penerima tamu saja. Dalam rumah tangga, perempuan adalah konco wingking di dapur.

3. Kaum perempuan berada dalam posisi yang lemah, karenanya kaum perempuan sering menjadi sasaran tindak kekerasan (violence) oleh kaum laki-laki. Dalam masyarakat, bentuk kekerasan itu mulai dari digoda, dilecehkan, dipukul, dicerai sampai diperkosa.

4. Akibat ketidakadilan gender itu, kaum perempuan harus menerima beban pekerjaan yang lebih berat dan lebih lama daripada yang dipikul kaum lakilaki. Dalam bekerja, laki-laki paling aktif maksimal bekerja rata-rata 10 jam/hari, sedangkan perempuan bekerja 18 jam/hari. Pada umumnya beban ini dianggap remeh oleh kaum laki-laki, karena secara ekonomi dinilai kurang berarti. ${ }^{19}$ 
Dengan demikian manifestasi ketidakadilan gender jika dirumuskan di dalam sektor kehidupan antara lain terdapat pada: Sektor Budaya, perempuan terkungkung dengan stereotip, 20 yang diletakkan pada dirinya untuk tidak keluar dari peran dommestiknya. Stereotype ini akan berimplikasi pada ketabuannya untuk dapat berpendidikan tinggi; Sektor Domestik dan publik, perempuan akan selalu menjadi korban kekerasan; Sektor ekonomi, perempuan mengalami marginalisasi dan dipaksa berperan ganda; Sektor Politik, perempuan menjadi subordinasi dari kekuasaan laki-laki.

Menurut Arief Budiman ada dua faktor yang mempertahankan pembagian peran dan atau kerja laki-laki dan perempuan yang bias gender. Pertama, faktor sosial ekonomi yang didasarkan pada kebutuhan nyata dari sistem masyarakat itu. Kedua, faktor ideologi atau sistem patriarkal/patriarkhi yang bukan hanya sekedar sistem kepercayaan abstrak belaka akan tetapi didukung oleh lembaga-lembaga kemasyarakatan yang menyebarkan, mengembang-biakkan dan melestarikannya. ${ }^{21}$

Secara etimologi kata patriarkhi digunakan untuk menyebutkan kekuasaan laki-laki. Ideologi patriarkhi membenarkan penguasaan satu kelompok terhadap kelompok lainnya, berdasarkan jenis kelamin. ${ }^{22}$ Asal usul kekuasaan laki-laki terhadap perempuan tidak diketahui karena bersifat universal, monolitis, dan tidak dapat dibantah, bahkan tidak dapat dihindarkan. ${ }^{23}$ Pada masyarakat patriarkhi, laki-laki diposisikan superior terhadap perempuan di sektor domestik dan publik. Hegemoni lakilaki atas perempuan memperoleh legetimasi dari nilai-nilai sosial, agama, hukum negara, dan sebagainya, dan tersosialisasi secara turun temurun dari generasi ke generasi. ${ }^{24}$ Dengan demikian secara ringkas dapat dipahami bahwa kata patriarkhi diartikan sebagai "men power" (kekuasaan laki-laki), karena pengaruh budaya patriarkhi, maka masyarakat memandang bahwa laki-laki mempunyai kedudukan yang lebih tinggi daripada perempuan dalam kehidupan.

Terkait dengan budaya patriarkhi, Islam tidak pernah melegitimasinya, karena misi pokok Al-Qur'an (Q.S.49: 13) diturunkan adalah untuk membebaskan manusia dari berbagai bentuk diskriminasi dan penindasan, termasuk diskriminasi seksual, gender, warna kulit, etnis, dan ikatan-ikatan primordial lainnya. 25 Islam sangat menghargai perempuan dan menjamin hakhak perempuan dan memberikan perhatian serta kedudukan terhormat kepada perempuan, yang hal ini tidak pernah dilakukan oleh agama atau syariat sebelumnya, oleh karena itu ideologi atau 
budaya patriarkhi bukan dari Islam, bahkan sangat bertentangan dengan Islam. ${ }^{26}$

\section{Pangkal Stereotip Gender: Asal-usul Kejadian Manusia}

Hampir semua agama dan kepercayaan membedakan asal-usul kejadian laki-laki dan perempuan. Agamaagama yang termasuk di dalam kelompok Abrahamic religions, yaitu Agama Yahudi, Agama Kristen, dan Agama Islam menyatakan bahwa laki-laki (Adam) diciptakan lebih awal dari pada perempuan. Di Dalam Bibel ditegaskan bahwa perempuan (Hawwa/Eva) diciptakan dari tulang rusuk Adam, seperti dapat dilihat pada Kitab Kejadian (Genesis) 1:26-27, 2:1824, Tradisi Imamat 2:7, 5:1-2. Tradisi Yahwis 2:18-24. Di antaranya yang paling jelas ialah Kitab Kejadian 2:21-23:

"21 Lalu Tuhan Allah membuat manusia itu tidur nyenyak; ketika tidur, Tuhan Allah mengambil salah satu rusuk dari padanya, lalu menutup tempat itu dengan daging. 22 Dan dari rusuk yang diambil Tuhan Allah dari manusia itu, dibangunNyalah seorang perempuan, lalu dibawaNya kepada manusia itu".27 (Bibel Edisi Indonesia).

Berbeda dengan Bibel, al-Qur'an menerangkan asal-usul kejadian tersebut di dalam satu ayat pendek (QS. al-Nisa' (4): 1):
“Hai sekalian manusia, bertakwalah kepada Tuhanmu yang telah menciptakan kamu dari "diri" yang satu, dan dari padanya Allah menciptakan pasangannya, dan dari pada keduanya Allah memperkembangbiakkan laki-laki dan perempuan yang banyak. Dan bertakwalah kepada Allah yang dengan (mempergunakan) nama-Nya kamu saling meminta satu sama lain, dan (peliharalah) hubungan silaturrahim. Sesungguhnya Allah selalu menjaga dan mengawasimu."

Cerita tentang asal-usul kejadian itu hanya ditemukan di dalam beberapa hadits.Keterangan dari Bibel dan haditshadits mengilhami para exegesist, mufassir, penyair, dan novelis menerbitkan berbagai karya. Karya-karya tersebut dapat mengalihkan pandangan bahwa seolah-olah manusia, terutama laki-laki, secara biologis adalah makhluk supernatural, terlepas sama sekali dengan makhluk biologis lainnya, seperti binatang dan tumbuh-tumbuhan. Tidak heran kalau Darwin dengan teori evolusinya dianggap "murtad" di kalangan kaum agamawan, karena mengembangkan faham yang bertentangan dengan teks Kitab Suci.

\section{Bias Gender dalam Pendidikan}

Rendahnya kualitas hidup perempuan Indonesia terlihat pada beberapa aspek diantaranya adalah pada aspek 
pendidikan. Fakta menunjukkan rendahnya angka partisipasi perempuan di jenjang pendidikan tinggi, yakni kurang dari 5\%. Semakin tinggi tingkat pendidikan, semakin tinggi tingkat disparitas (ketidakseimbangan) gendernya. Data lainnya adalah angka buta huruf dikalangan perempuan masih sangat tinggi: kurikulum serta materi bahan ajar masih sangat bias gender; dan hampir seluruh proses pengelolaan pendidikan masih dirumuskan berdasarkan pandangan yang bias sebagai akibat dari masih dipegangnya sebagian besar penentu kebijakan pendidikan oleh laki-laki.28

Pendidikan di sekolah dengan komponen pembelajaran seperti media, metode, serta buku ajar yang menjadi pegangan para siswa ternyata sarat dengan bias gender.

Dalam buku ajar misalnya, banyak ditemukan gambar maupun rumusan kalimat yang tidak mencerminkan kesetaraan gender. Sebut saja gambar seorang pilot selalu laki-laki karena pekerjaan sebagai pilot memerlukan kecakapan dan kekuatan yang "hanya" dimiliki oleh laki-laki. Sementara gambar guru yang sedang mengajar di kelas selalu perempuan karena guru selalu diidentikkan dengan tugas mengasuh atau mendidik. Ironisnya siswa pun melihat bahwa meski gurugurunya lebih banyak berjenis kelamin perempuan, tetapi kepala sekolahnya umumnya laki-laki. Dalam rumusan kalimat pun demikian. Kalimat seperti "Ini ibu Budi" dan bukan "ini ibu Suci", "Ayah membaca Koran dan ibu memasak di dapur" dan bukan sebaliknya "Ayah memasak di dapur dan ibu membaca koran", masih sering ditemukan dalam banyak buku ajar atau bahkan contoh rumusan kalimat yang disampaikan guru di dalam kelas. Rumusan kalimat tersebut mencerminkan sifat feminim dan kerja domestik bagi perempuan serta sifat maskulin dan kerja public bagi laki-laki.

Demikian pula dalam perlakuan guru terhadap siswa, yang berlangsung di dalam atau di luar kelas. Misalnya ketika seorang guru melihat murid laki-lakinya menangis, ia akan mengatakan "Masak laki-laki menangis. Laki-laki nggak boleh cengeng". Sebaliknya ketika melihat murid perempuannya naik ke atas meja misalnya, ia akan mengatakan "anak perempuan kok tidak tahu sopan santun". Hal ini memberikan pemahaman kepada siswa bahwa hanya perempuan yang boleh menangis dan hanya laki-laki yang boleh kasar dan kurang sopan santunnya.

Dalam upacara bendera di sekolah selalu bisa dipastikan bahwa pembawa bendera adalah siswa perempuan. Siswa perempuan itu dikawal oleh dua siswa lakilaki. Hal demikian tidak hanya terjadi di tingkat sekolah, tetapi bahkan di tingkat 
Syafrida, Evaluasi Materi Pendidikan Islam Perspektif Gender...

nasional. Paskibraka yang setiap tanggal 17 Agustus bertugas di Istana Negara, selalu menempatkan dua perempuan sebagai pembawa bendera pusaka dan duplikatnya. Belum pernah terjadi dalam sejarah: laki-laki yang membawa bendera pusaka itu.

Hal ini menanamkan pengertian kepada siswa dan masyarakat pada umumnya bahwa tugas pelayanan seperti membawa bendera, lebih luas lagi, membawa baki atau pemukul gong dalam upacara resmi sudah selayaknya menjadi tugas perempuan. Semuanya ini mengajarkan kepada siswa tentang apa yang layak dan tidak layak dilakukan oleh laki-laki dan apa yang layak dan tidak layak di lakukan oleh perempuan.

Bias gender yang berlangsung di rumah maupun di sekolah tidak hanya berdampak negatif bagi siswa atau anak perempuan tetapi juga bagi anak laki-laki. Anak perempuan diarahkan untuk selalu tampil cantik, lembut, dan melayani. Sementara laki-laki diarahkan untuk tampil gagah, kuat, dan berani. Ini akan sangat berpengaruh pada peran social mereka di masa datang.

Singkatnya, ada aturan-aturan tertentu yang dituntut oleh masyarakat terhadap perempuan dan laki-laki. Jika perempuan tidak dapat memenuhinya ia akan disebut tidak tahu adat dan kasar. Demikian pula jika laki-laki tidak dapat memenuhinya ia akan disebut banci, penakut atau bukan laki-laki sejati.

William Pollacek dalam Real Boys menunjukkan penemuannya, sebenarnya, bayi laki-laki secara emosional lebih ekspresif dibandingkan bayi perempuan. Namun ketika sampai pada usia sekolah dasar, ekspresi emosionalnya hilang. Laki-laki pada usia lima atau enam tahun belajar mengontrol perasaanperasaannya dan mulai malu mengungkapkannya.

Penyebabnya adalah pertama, ada proses menjadi kuat bagi laki-laki yang selalu diajari untuk tidak menangis, tidak lemah, dan tidak takut. Kedua, proses pemisahan dari ibunya, yakni proses untuk tidak menyerupai ibunya yang dianggap masyarakat sebagai perempuan lemah dan harus dilindungi. Meski berat bagi anak lakilaki untuk berpisah dari sang ibu, namun ia harus melakukannya jika tidak ingin dijuluki sebagai "anak mami".

Tidak mengherankan jika banyak guru mengatakan bahwa siswa laki-laki lebih banyak masuk dalam daftar penerima hukuman, gagal studi, dan malas. Penyebabnya menurut Sommers, karena anak laki-laki lebih banyak mempunyai persoalan hiperaktif yang mengakibatkan kemunduran konsentrasi dikelas.

Sementara itu, menjelang dewasa, pada anak perempuan selalu ada tuntutantuntutan di luar dirinya yang memaksa mereka tidak memiliki pilihan untuk 
bertahan. Satu-satunya cara yang dianggap aman adalah dengan membunuh kepribadian mereka untuk kemudian mengikuti keinginan masyarakat dengan menjadi suatu objek yang diinginkan oleh laki-laki. Objek yang diinginkan ini selalu berkaitan dengan tubuhnya.

Jadilah mereka kemudian anak-anak perempuan yang mengikuti stereotip yang diinginkan seperti tubuh langsing, wajah putih nan cantik, kulit halus dan lain sebagainya. Tidak heran jika semakin banyak anak perempuan mengusahakan penampilan sempurna bak peragawati dengan cara-cara yang justru merusak tubuhnya.

Padahal, di sekolah, siswa perempuan umumnya memiliki prestasi akademik yang lebih baik jika dibandingkan dengan lakilaki. Situasi dan kondisi memungkinkan mereka jauh lebih tekun dan banyak membaca buku.

\section{Bias Gender dalam buku ajar Agama Islam}

Terdapat beberapa bagian yang bias gender dalam kurikulum agama Islam diantaranya pada materi tentang asal kejadian manusia, “ dijelaskan bahwa lakilaki diciptakan dari tanah sementara perempuan di ciptakan dari tulang rusuk Nabi Adam" . selanjutnya dijelaskan sebab manusia terusir dari syurga adalah karena Nabi Adam dan Siti Hawa memakan buah quldi, yang mana Siti Hawa dibujuk oleh Syaithan untuk memakan buah quldi, seterusnya Siti Hawa membujuk Nabi Adam untuk mau mengikuti saran syaithan". Berdasarkan sejarah yang yang dipaparkan bahwa perempuan tercipta dari bagian tubuh laki-laki yaitu tulang rusuk yang bengkok, ini mengindikasikan bahwa perempuan tidak sama dengan laki-laki tapi adalah bagian dari laki-laki. Pada giliran membawa pemahaman bahwa perempuan adalah manusia yang lemah. Dari kisah terusirnya Nabi Adam dan Siti Hawa dari syurga karena Siti Hawa yang membujuk Nabi Adam untuk memakan buah quldi. ini mengisyaratkan bahwa perempuan mudah digoda oleh syaithan, selanjutnya perempuan sering menjerumuskan laki-laki dengan bujuk rayunya, yang notabenenya membawa pemahaman bahwa perempuan adalah manusia penggoda dan sering menjerumuskan pasangannya.

Selain itu, dalam buku-buku ajar agama Islam untuk SD mulai kelas 1-3, Kisah-kisah Nabi dan Rasul diceritakan hanya kisah Nabi dan Rasul dari kaum lakilaki saja. ${ }^{29} \mathrm{Hal}$ senada juga dapat dilihat pada tema Profil tokoh di dalam buku ajar SMP kelas 3 terbitan Ganeca ${ }^{30}$ juga pada tema Sepenggal Kisah atau Kisah Islami dalam buku ajar SD Kelas 1-6 terbitan Erlangga. Di dalam dua buku terakhir yang penulis sebutkan profil tokoh yang dikisahkan lebih 
banyak pada gambaran ketokohan dan ketauladanan seorang laki-laki dibandingkan perempuan. ${ }^{31}$ Dari teks di atas dapat dipahami bahwa yang dapat menjadi orang baik adalah laki-laki, sedangkan perempuan tidak dapat menjadi seorang yang menjadi suri tauladan. ${ }^{32}$

Bias Gender yang lain dalam buku ajar Agama Islam juga terdapat dalam bentuk gambar dimana dalam topik Takabur(sombong) digambarkan sekelompok perempuan yang sedang membicarakan seorang perempuan yang sombong. Secara implisit ilustrasi gambar yang diberikan juga telah menumbuhkan dan membangun bias gender bagi yang membaca ataupun melihatnya dimana perempuan akan diidentikan dengan sosok yang suka mengunjing, menggosip dan sebagainya. Hal senada juga dapat dilihat pada bahasan rukun iman dimana terdapat satu keluarga yang sedang beraktifitas; sosok anak lakilakinya digambarkan sedang belajar, Ayahnya sedang melihat pemandangan, sementara si Ibu memasak di dapur. ${ }^{33}$

Selain melalui gambar, bias gender juga dapat terlihat pada ungkapan ataupun narasi kalimat dalam uraian materi. Dalam uraian pokok bahasan adab makan dan minum, terdapat kalimat, "kemudian bantulah ibumu membereskan meja makan' dengan ilustrasi gambar adegan keluarga yang selesai makan,si Ibu dan anak perempuan membereskan peralatan makan, sementara ayah dan anak laki-lakinya sedang berbincang-bincang. ${ }^{34} \mathrm{Hal}$ ini jelas sekali menunjukkan domestifikasi pekerjaan perempuan.

Kalimat-kalimat di atas tersebut mensosialisikan domestifikasi pekerjaan perempuan dalam rumah tangga. Sementara itu dalam tema-tema tentang wudu, salat berjama'ah (fiqih) mayoritas gambar yang dibuat adalah gambar laki-laki. Penggambaran ini bagi penulis juga bernuasa bias gender karena kewajiban pelaksanaan dan praktek ibadah (fiqih) tidak hanya dibebankan kepada laki-laki tetapi juga bagi perempuan. ${ }^{35}$

Persoalan bias gender dalam masalah fiqih yang lain, adalah tentang salat jama'ah, dan munakahat. Dalam buku pendidikan Agama Islam untuk SD KELAS 3 Bab VI tentang Shalat jama'ah 36 dijelaskan bahwa ketentuan menjadi imam, yaitu :(a)laki-laki mengimami laki-laki-laki; (b)laki-laki mengimami perempuan; (c)perempuan mengimami pertempuan; (d)laki-laki mengimami banci; (e)banci mengimami perempuan ${ }^{37}$. Dalam buku itu, Latihan II No.3, terdapat pertanyaan: " Bolehkan perempuan mengimami laki-laki ?"

Hal senada juga terdapat dalam buku Integrasi Budi Pekerti dalam Pendidikan Agama Islam untuk kelas 1 SLTP, Bab VII tentang salat berjama'ah,dijelaskan bahwa syarat-syarat menjadi imam, yaitu; (a)sehat akalnya; (b)harus baik dan benar bacaannya; 
(c)harus laki-laki ( tidak boleh perempuan menjadi imam laki-laki; (d)lebih tua umurnya; (f)hendaknya memiliki pengetahuaan yang memadai, khususnya tentang salat berjama'ah 38

Dari teks di atas, dapat dipahami bahwa perempuan tidak dapat menjadi imam bagi laki-laki dengan dipertegas salah satu syarat untuk menjadi imam adalah harus laki- laki (tidak boleh perempuan menjadi imam). Dari teks ini timbul pertanyaan, "Mengapa perempuan tidak boleh mengimami laki-laki?', “bagaimana jika yang menjadi makmum itu laki-laki yang masih kanak-kanak?”, “ atau bolehkah perempuan mengimami laki-laki karena bacaan salatnya lebih fasih dan 'alim dibandingkan laki-laki yang menjadi makmum?'.

Dalam buku Integrasi Budi Pekerti dalam Pendidikan Agama Islam untuk kelas 1 SLTP, Bab XII tentang munakahat, dijelaskan bahwa" dalam ajaran Islam tidak ada larangan seorang laki-laki beristri sampai batas empat. Akan tetapi, untuk melaksanakan hal itu harus dapat memenuhi syarat-syarat yang sangat berat, yaitu bisa berlaku adil dalam mengatur kebutuhan tiaptiap istri". Dasar hukum yang digunakan adalah surah An-Nisa : 3. Selain itu, dijelaskan bahwa salah satu alasan boleh melakukan poligami adalah untuk menghindarkan seorang laki-laki melakukan perzinahan, karena istrinya dalam keadaan sakit yang menahun dan tidak dapat melaksanakan kewajibannya sebagai seorang istri, dan sebaginya. 39

Dari teks tersebut, tampak bahwa dasar hukum bagi poligami diambil dari surat An-Nisa ayat 3 dan Undang-undang Perkawinan No 1 Tahun 1974 pasal 5 tentang poligami yang menjelaskan bolehnya poligami yaitu :(1) Istri tidak dapat menjalankan kewajiban sebagai istri; (2) Istri mendapat cacat badan atau penyakit yang tidak dapat disembuhkan dan (3) Istri tidak dapat melahirkan keturunan.

Berdasarkan Asbab an-Nuzul diketahui jelas permasalahan ayat tersebut bukan dalam konteks perkawinan melainkan dalam konteks pemeliharaan anak yatim. Dalam masalah ini penyusun buku tampaknya memandang alasan dibolehkannya praktik berpoligami hanya dilihat dari perspektif kepentingan laki-laki, tidak mempertimbangkan kepentingan perempuan. ${ }^{40}$

\section{Rekonstruksi Materi Pendidikan Agama Islam}

Dalam upaya mewujudkan pemahaman keagamaan yang bersifat gender, maka perlu diadakan pembukaan ruang keadilan gender melalui optimalisasi proses pendidikan Islam. Optimalisasi yang 
dimaksudkan adalah upaya untuk mengikis bias gender yang terjadi dalam segala proses pendidikan Islam. Optimalisasi tersebut meliputi optimalisasi tujuan, metode,dan materi pendidikan Islam. Tujuan pendidikan Islam bisa dioptimalkan melalui perumusan kembali tujuan pendidikan yang tidak mengarah kepada bias gender. Yaitu dengan lebih memprioritaskan kepada:1)peneguhan nilai kemanusiaan tanpa membedakan jenis kelamin. 2)pengembangan pengetahuan secara dinamis agar tidak tertinggal 3) membentuk kesadaran individu yang mempunyai kepekaan sosial 4) komunikasi secara terbuka 5) tanpa membedakan jenis kelamin.

Dengan demikian sudah selayaknya diperlukan revisi terhadap materi-materi yang bias gender dalam buku ajar Agama Islam tersebut. Revisi ini menjadi penting dikarenakan pemahaman keagamaan yang bias ini jusru menjadi pemahaman mayoritas di masyarakat. Kenyataan ini dilatar belakangi karena umat Islam memahami ajaran agamanya secara dogmatis dan bukan berdasarkan penalaran yang kritis kususnya pengetahuan agama yang menjelaskan peran dan kedudukan perempuan.

Perlu ditekankan pula penyadaran tentang nilai-nilai pendidikan yang berperspektif gender kepada semua pihak khususnya para pengarang dan editor buku tentang kenyataan bahwa materi buku ajar yang ada tidak netral gender artinya disusun dan dirumuskan dengan sudut pandang lakilaki. Sehingga mereka tidak lagi membuat gambar ataupun narasi bahan ajar agama yang bias gender. Sementara itu, bagi para guru agama dituntut untuk lebih kritis dan sensitif dalam menelaah dan mencermati segala hal yang terkait dengan ketimpangan gender dalam proses pembelajaran yang berlangsung dalam kerja kesehariannya.

\section{KESIMPULAN}

Tidak dapat dipungkiri bahwa banyak ketentuan hukum Islam yang membedakan norma hukum untuk laki-laki dan perempuan. Namun perbedaan tersebut tidak menyebabkan terjadinya kesenjangan dan ketidakadilan, semuanya bermuara untuk saling melengkapi. Ketidakadilan yang terjadi selama ini lebih disebabkan oleh hukum Islam yang dipahami secara tekstual, dan juga budaya yang sudah mendarah daging dalam kehidupan masyarakat yang mulai dari keluarga, masyarakat dan lingkungan sekolah.

Pada akhirnya kesetaraan gender dalam proses pembelajaran memerlukan keterlibatan seluruh pihak, Depag, Depdiknas sebagai pengambil kebijakan di bidang pendidikan, sekolah secara kelembagaan dan terutama guru. Dalam hal ini diperlukan standardisasi buku ajar yang salah satu kriterianya adalah berwawasan gender. Selain itu, guru akan menjadi agen 
perubahan yang sangat menentukan bagi terciptanya kesetaraan gender dalam pendidikan melalui proses pembelajaran

\section{Endnotes:}

1 Ahmad Tafsir, Flsafat Pendidikan Islam (Bandung: PT Remaja Rosda Karya, 2006), hal. 33.

2 Rr. Suhartini, "Dimensi Gender dalam Pemberdayaan Masyarakat di Daerah Rawan Longsor", dalam Model-model.

3 Louise Ricklander, "Women and Politics", dalam Women at work Psychological and Organizaational Perspective, ed. Michael A. West (Philadelphia : Open University Press, 1993), Hal 183

4 Siti Kusujiarti, "Antara Ideologi dan Transkrip Tersembunyi: Dinamika Hubungan Gneder dalam Masyarakat Indonesia" dalam Irwan Abdullah, Sangkan Paran Gender (Yogyakarta: Pustaka Pelajar, 1997), Hal. 82

5 Asriati Djamil dan Lubis, A., Seks dan gender. Dalam Pengantar Kajian Gender, (Jakarta: PSW UIN Syarif Hidayatullah kerja sama dengan McGill Project/IISEP, 2003), Hal. 53

6 Echols, J.M. dan Hassan Sadily, Kamus Inggris Indonesia . ( Jakarta: PT. Gramedia Pustaka Utama, 1997), Hal. 517

7 Asriati, loc. cit.

${ }^{8}$ Hornby, AS. (1987). Oxford advanced dictionary of current English, (London: Oxford University Press, 1987), Hal. 357

9 Mosse, J.C., Half the worl, half a chance an introduction to gender and development, Terjemahan Hartian Silawati, Gender dan Pembangunan, (Oxford: Oxfam, 1985), Hal. 2

${ }^{10}$ Mansour Fakih, Analisis gender dan transformasi social, ( Yoyakarta: Pustaka Pelajar 2005), Hal. 8

11 Nasaruddin Umar, Argumen kesetaraan gender: perspektif Alqur'an, ( Jakarta: Paramadina, 2002), Hal. 4 yang peka gender.

12 Moser, C.O.N., Gender planing and development; theory, practice and training, (London: Routledge, 1993), Hal. 28

${ }^{13}$ Arief Budiman, Pembagian Kerja Secara seksual, Sebuah Pembahasan Sosiologis tentang Peran Wanita di dalam Masyarakat, ( Jakarta: PT Gramedia, 1985), Hal. 34

14 Perbedaan gender selanjutnya melahirkan peran gender yang sesungguhnya tidaklah menimbulkan masalah, sehingga tidak perlu digugat, jadi kalau secara biologis (kodrat) kaum perempuan dengan organ reproduksinya bisa hamil, melahirkan dan menyusui dan kemudian mempunyai peran gender sebagai perawat, penagsuh dan pendidik anak, sesungguhnya tidak masalah dan tidak perlu digugat, akan tetapi, yang menjadi masalah dan perlu digugat oleh mereka yang menggunakan analisa gender adalah struktur ketidakadilan tersebut. dari studi yang dilakukan dengan menggunakan analisis gender ternyata banyak ditemukan berbagai manifestasi ketidakadilan. Mansour Fakih, loc. cit.

15 Noryamin Aini, Jender dalam Diskursus Keislaman; Relasi Jender dalam Pandangan Fiqih, dalam Refleksi , (Jakarta; Jurnal kajian Agama dan Filsafat, 2001), Vol. III. No.2, Hal. 4

16 Masdar.F. Mas'udi, Perempuan dalam Wacana Keislaman, dalam Smita Notosutanto dan E. Kristi Poerwandari ( peny, Perempuan dan Pemberdayaan : Kumpulan Karangan untuk Menghormati Ulang tahun ke -70 Ibu Saparinah Saalli, cet. I, ( Jakarta: Yayasan Obor Indonesia, 1997), Hal. 55-56

17 Subordinasi Artinya suatu penilaian atau anggapan bahwa suatu peran yang dilakukan oleh satu jenis kelamin lebih rendah dari yang lain. Dalam rumah tangga, masyarakat maupun Negara,banyak kebijakan dibuat tanpa "meganggap penting" kaum perempuan. Ibid. lihat juga https://sofyaneffendi.wordpress.com/2011/0 
7/26/macam-macam-ketidakadilan-gender/ diakses, 24 Maret 2015

18 Marginalisasi artinya suatu proses peminggiran akibat perbedaan jenis kelamin yang mengakibatkan kemiskinan. Misalnya, guru taman kanak-kanak atau pekerjaan sekretaris dinilai lebih rendah dibanding pekerjaan laki-laki, dan seringkali berpengaruh terhadap perbedaan gaji antara kedua jenis pekerjaan tersebut. Ibid.

${ }^{19}$ Ibid., Hal. 56-57

20 Pelabelan negatif secara umum selalu melahirkan ketidakadilan. Salah satu stereotipe yang berkembang berdasarkan pengertian gender, yakni terjadi terhadap salah satu jenis kelamin, (perempuan),Hal ini mengakibatkan terjadinya diskriminasi dan berbagai ketidakadilan yang merugikan kaum perempuan. Misalnya pandangan terhadap perempuan yang tugas dan fungsinya hanya melaksanakan pekerjaan yang berkaitan dengan pekerjaan domistik atau kerumahtanggaan. Ibid. Hal. 9

21 Arief Budiman, op. cit.,h. 34

22 Muhadjir Darwin, \& Tukiran, Menggugat Budaya Patriarkhi, (Yogyakarta: Pusat Penelitian Kependudukan UGM, 2001), Hal. 24

${ }^{23}$ Asriati Djamil,op. cit., h. 60

${ }^{24}$ Muhadjir Darwin dan Tukiran, op. cit., Hal. 24

${ }^{25}$ Nasaruddin Umar, op. cit., Hal. 15

26 Salih Ibrahim Suad, Kedudukan Perempuan Dalam Islam. Dalam Atho Mudzhar (Ed) Wanita dalam Masyarakat Indonesia; Akses,Pemberdayaan dan Kesempatan, ( Yogyakarta: Sunan Kalijaga Press, 2001), Hal. 37

27 Bibel Edisi Indonesia

28 Sebagai bukti bahwa pemegang kebijakan dalam bidang pendidikan lebih di dominasi laki-laki dibandingkan perempuan dapat dilihat pada perbandingan dari setiap 100 guru SD, 54 orang adalah perempuan dan dari 100 guru sekolah menengah, 38 orang diantaranya adalah perempuan. Sementara itu tenaga dosen lebih dominan laki-laki, dari 100 dosen hanya 29 orang adalah perempuan. ${ }^{28}$ Kepemimpinan dalam pendidikan juga lebih didominasi laki-laki dibandingkan perempuan. Musdah Mulia, Menggagas Kurikulum Yang berperspektif Gender, ( Jakarta : Jurnal Inovasi, Vol VI/ No .01/ 2003), Hal 22

29 Tim KKG PAI, Integrasi Budi Pekerti dalam Pendidikan Agama Islam untuk SD kelas 4, ( Jakarta ; Ghalia Indonesia, 2002), Hal125

30 Drs. Achmadi Wahid, M. Ag dan Drs. H. Masrun, Pendidikan Agama Islam untuk SMP kelas 3, ( Jakarta: Ganeca Exact, 2005)

${ }^{31}$ New Teaching Resources, Pendidikan Agama Islam SD untuk kelas I-VI, ( Jakarta : Esis Erlangga, 2004.

32 Penulis pernah mencoba membahas seberapa jauh tingkat kesadaran akan pemahaman gender pada siswa dan Siswi kelas 7 dalam bentuk diskusi . Pada umumnya kelompok siswa mendefinisikan keunggulan nya dari sisi fisik dibandingkan siswi hingga sampai pada "keunggulan laki-laki" karna Nabi dan Rasul juga dari laki-laki yang membuat kelompok siswi terpojokkan dalam diskusi tersebut.

33 Tim Penyusun buku Agama Islam kelas 3, ( Jakarta : Erlangga, 2003), Hal. 11

34 Ibid. Hal. 31

35 Penulis telah meneliti ilustrasi gambar dalam buku ajar Agama Islam khususnya pada tingkat SD dari 4 penerbitan yang berbeda, mayoritas ilustrasi gambar yang digunakan dalam berwudhu, tayammum serta cara pelaksanaan 13 rukun salat tidak satupun penulis lihat yang mengikutsertakan gambar perempuan. Dalam Salat Berjama'ah juga mayoritas gambar yang dibuat lebih banyak kelompok laki-laki hanya sedikit yang mengikut sertakan gambar perempuan dalam tema salat berjama'ah. [20] Lihat juga buku Tim Abdi Guru, Ayo Belajar Agama Islam untuk SMP kelas VII, ( Jakarta: Erlangga, 2004), Hal.151-155

${ }^{36}$ Cholil Umam, dkk., Pendidikan Agama Islam untuk SD Kelas 3, ( Sidoarjo: Duta Aksara, 2003), Hal. 42 
37 Ahmad Syafi'i Mufid, Integrasi Budi Pekerti dalam Pendidikan Agama Islam untuk kelas 1 SLTP, ( Jakarta: Ghalia Indonesia, 2002), h. 66

38 Ahmad Syafi'i Mufid, Ibid, h. 111

39 Tim Abdi Guru: M. Nasikhin dan Hanif Nurcholish, Pedoman Belajar Agama Islam untuk SLTP KELAS 2, ( Jakarta : Gelora Aksara Pratama, 2003), h. 112-113

40 Huzaemah Tahido Yanggo, 'Pandangan Islam tentang Gender, ' dalam Mansour Faqih, Membincang Feminisme: Diskursus Gender Persfektif Islam, cet. I, ( Surabaya: Risalah Gusti, 1996), h. 155

\section{DAFTAR PUSTAKA}

Ahmad Tafsir, Flsafat Pendidikan Islam (Bandung: PT Remaja Rosda Karya, 2006).

Achmadi Wahid, M. Ag dan Drs. H. Masrun, Pendidikan Agama Islam untuk SMP kelas 3, (Jakarta: Ganeca Exact, 2005)

Ahmad Syafi'i Mufid, Integrasi Budi Pekerti dalam Pendidikan Agama Islam untuk kelas 1 SLTP, (Jakarta: Ghalia Indonesia, 2002).

Arief Budiman, Pembagian Kerja Secara seksual, Sebuah Pembahasan Sosiologis tentang Peran Wanita di dalam Masyarakat, (Jakarta: PT Gramedia, 1985).

Asriati Djamil dan Lubis, A., Seks dan gender. Dalam Pengantar Kajian Gender, (Jakarta: PSW UIN Syarif Hidayatullah kerja sama dengan McGill Project/IISEP, 2003).

Cholil Umam, dkk., Pendidikan Agama Islam untuk SD Kelas 3, (Sidoarjo: Duta Aksara, 2003).
Echols, J.M. dan Hassan Sadily, Kamus Inggris Indonesia . (Jakarta: PT. Gramedia Pustaka Utama, 1997).

Hornby, AS. (1987). Oxford advanced dictionary of current English, (London: Oxford University Press, 1987).

Louise Ricklander, "Women and Politics", dalam Women at work Psychological and Organizaational Perspective, ed. Michael A. West (Philadelphia : Open University Press, 1993).

Mansour Fakih, Analisis gender dan transformasi social, (Yoyakarta: Pustaka Pelajar 2005).

Moser, C.O.N., Gender planing and development; theory, practice and training, (London: Routledge, 1993).

Mosse, J.C., Half the worl, half a chance an introduction to gender and development, Terjemahan Hartian Silawati, Gender dan Pembangunan, (Oxford: Oxfam, 1985).

Muhadjir Darwin, \& Tukiran, Menggugat Budaya Patriarkhi, (Yogyakarta: Pusat Penelitian Kependudukan UGM, 2001).

Musdah Mulia, Menggagas Kurikulum Yang berperspektif Gender, ( Jakarta : Jurnal Inovasi, Vol VI/ No .01/ 2003).

Nasaruddin Umar, Argumen kesetaraan gender: perspektif Alqur'an, (Jakarta: Paramadina, 2002). 
New Teaching Resources, Pendidikan Agama Islam SD untuk kelas I-VI, ( Jakarta : Esis Erlangga, 2004.

Noryamin Aini, Jender dalam Diskursus Keislaman; Relasi Jender dalam Pandangan Fiqih, dalam Refleksi, (Jakarta; Jurnal kajian Agama dan Filsafat, 2001), Vol. III. No.2.

Rr. Suhartini, “Dimensi Gender dalam Pemberdayaan Masyarakat di Daerah Rawan Longsor", dalam Model-model.

Salih Ibrahim Suad, Kedudukan Perempuan Dalam Islam. Dalam Atho Mudzhar (Ed) Wanita dalam Masyarakat Indonesia; Akses,Pemberdayaan dan Kesempatan, ( Yogyakarta: Sunan Kalijaga Press, 2001)

Siti Kusujiarti, "Antara Ideologi dan Transkrip Tersembunyi: Dinamika Hubungan Gneder dalam Masyarakat Indonesia" dalam Irwan Abdullah, Sangkan Paran Gender (Yogyakarta: Pustaka Pelajar, 1997).

Tim Abdi Guru: M. Nasikhin dan Hanif Nurcholish, Pedoman Belajar Agama Islam untuk SLTP KELAS 2, (Jakarta: Gelora Aksara Pratama, 2003)

Tim KKG PAI, Integrasi Budi Pekerti dalam Pendidikan Agama Islam untuk SD kelas 4, ( Jakarta ; Ghalia Indonesia, 2002).

Tim Penyusun buku Agama Islam kelas 3, ( Jakarta : Erlangga, 2003) 